\title{
Genetic parameters between feed-intake-related traits and conformation in 2 separate dairy populations-the Netherlands and United States
}

\author{
C. I. V. Manzanilla-Pech, ${ }^{*} \dagger \ddagger^{1}$ R. F. Veerkamp, ${ }^{\star} \dagger$ R. J. Tempelman,§ M. L. van Pelt, ${ }^{\star} \#$ K. A. Weigel,II \\ M. VandeHaar,§ T. J. Lawlor,ף D. M. Spurlock, ${ }^{* *}$ L. E. Armentano,Il C. R. Staples,†† M. Hanigan,ł‡ \\ and Y. De Haas* \\ ${ }^{*}$ Animal Breeding and Genomics Centre, Wageningen UR Livestock Research, PO Box 338, 6700 AH Wageningen, the Netherlands \\ †Animal Breeding and Genomics Centre, Wageningen University, PO Box 338, $6700 \mathrm{AH}$ Wageningen, the Netherlands \\ $\ddagger$ Mococha Research Station, National Institute of Forestry, Agriculture and Livestock Research, 97454 Mococha, Yucatan, Mexico \\ §Department of Animal Science, Michigan State University, East Lansing 48824 \\ \#CRV BV, Animal Evaluation Unit, PO Box 454, 6800 AL Arnhem, the Netherlands \\ IIDepartment of Dairy Science, University of Wisconsin, Madison 53706 \\ ףHolstein Association, Brattleboro, VT 05301 \\ **Department of Animal Science, lowa State University, Ames 50011 \\ ††Department of Animal Sciences, University of Florida, Gainesville 32611 \\ ¥¥Department of Dairy Science, Virginia Tech, Blacksburg 24061
}

\section{ABSTRACT}

To include feed-intake-related traits in the breeding goal, accurate estimates of genetic parameters of feed intake, and its correlations with other related traits (i.e., production, conformation) are required to compare different options. However, the correlations between feed intake and conformation traits can vary depending on the population. Therefore, the objective was to estimate genetic correlations between 6 feed-intake-related traits and 7 conformation traits within dairy cattle from 2 countries, the Netherlands (NL) and the United States (US). The feed-intake-related traits were dry matter intake (DMI), residual feed intake (RFI), milk energy output (MilkE), milk yield (MY), body weight (BW), and metabolic body weight (MBW). The conformation traits were stature (ST), chest width (CW), body depth (BD), angularity (ANG), rump angle (RA), rump width (RW), and body condition score (BCS). Feed intake data were available for 1,665 cows in NL and for 1,920 cows in US, from 83 nutritional experiments (48 in NL and 35 in US) conducted between 1991 and 2011 in NL and between 2007 and 2013 in US. Additional conformation records from relatives of the animals with DMI records were added to the database, giving a total of 37,241 cows in NL and 28,809 in US with conformation trait information. Genetic parameters were estimated using bivariate animal model analyses. The model included the following fixed effects for feed-intake-related traits: location by experiment-ration, age of cow at

Received April 20, 2015.

Accepted September 15, 2015.

${ }^{1}$ Corresponding author: coralia.manzanillapech@wur.nl calving modeled with a second order polynomial by parity class, location by year-season, and days in milk, and these fixed effects for the conformation traits: herd by classification date, age of cow at classification, and lactation stage at classification. Both models included additive genetic and residual random effects. The highest estimated genetic correlations involving DMI were with $\mathrm{CW}$ in both countries ( $\mathrm{NL}=0.45$ and $\mathrm{US}=0.61$ ), followed by ST $(\mathrm{NL}=0.33$ and $\mathrm{US}=0.57), \mathrm{BD}(\mathrm{NL}=$ 0.26 and $\mathrm{US}=0.49)$, and $\mathrm{BCS}(\mathrm{NL}=0.24$ and $\mathrm{US}=$ $0.46)$. The MilkE and MY were moderately correlated with ANG in both countries (0.33 and 0.47 in NL, and 0.36 and 0.48 in US). Finally, BW was highly correlated with CW (0.77 in NL and 0.84 in US) and with BCS (0.83 in NL and 0.85 in US). Feed-intake-related traits were moderately to highly genetically correlated with conformation traits (ST, CW, BD, and BCS) in both countries, making them potentially useful as predictors of DMI.

Key words: feed intake, conformation trait, genetic correlation

\section{INTRODUCTION}

Feed intake accounts for approximately $50 \%$ of variable costs in dairy production in Europe (EU, 2011). Including feed intake or feed efficiency in the selection index is worthwhile to reduce feed costs (Kennedy et al., 1993; de Haas et al., 2012; Veerkamp et al., 2012). Reducing feed intake, while increasing production in the breeding objective, should improve feed efficiency and hence farmer profit, provided that other economically important traits, such as fertility and health, are maintained. To be able to include feed intake in the 
selection index, specialized equipment is required to obtain individual DMI records. This equipment is expensive to buy and labor intensive to use. Therefore, it is unrealistic that large numbers of records will be obtained to allow accurate estimation of genetic parameters to predict breeding values in a progeny testing scheme.

Another option is to use other traits as predictors, such as production traits (e.g., milk, fat, and protein content) that have been shown to have strong genetic correlations with DMI (Veerkamp and Emmans, 1995; Veerkamp and Brotherstone, 1997; Manzanilla-Pech et al., 2014). Other possible predictor traits are conformation traits or linear type traits, which describe a range of visual characteristics of an animal (Berry et al., 2004), or BCS, which is an estimate of the fat storage (Waltner et al., 1993). Body condition score and chest width $(\mathbf{C W})$ are highly correlated with BW and have moderate to high heritabilities (Short and Lawlor, 1992). Several studies have already demonstrated that conformation traits are indeed useful as genetic predictors of DMI and feed efficiency in Holsteins (Veerkamp et al., 1994; Parke et al., 1999; Battagin et al., 2012).

Accurate estimates of genetic and residual correlations between feed-intake-related traits and conformation traits are required to compare the different options of including the latter as predictor traits for DMI within a selection index. However, estimated genetic parameters can vary depending on the population in which they are estimated (van Oers and Sinn, 2011). For instance, due to different selection history, genetic correlations between type and feed intake might differ. The objective of this study was to estimate genetic correlations between 6 feed-intake-related traits and 7 conformation traits for dairy cattle from 2 different countries: the Netherlands (NL) and the United States (US).

\section{MATERIALS AND METHODS}

\section{Selection of the Traits}

A careful selection of traits was conducted based on both nutritional and genetic perspectives. Some of the traits are obviously related together because of the trait definition [e.g., milk yield (MY) with milk energy (MilkE), and BW with metabolic BW (MBW)]. Some other traits include part-whole relationships [e.g., DMI with residual feed intake (RFI), MilkE with protein and fat content]. The purpose of this paper was to estimate the genetic correlations between all feed-intakerelated traits (i.e., DMI, RFI, MY, MilkE, BW, and $\mathrm{MBW}$ ) and various conformation traits to be able to determine which traits might be most useful to include in a selection index.

\section{Data Collection and Editing: Feed Intake Traits}

The Netherlands. Weekly data on MY, DMI, and BW were available from 2,283 cows that participated in nutritional experiments that were conducted on several Dutch farms during 1986 to 2010. A description of the methodology of most experiments and of the content of the diets has been summarized previously (Veerkamp et al., 2000; Beerda et al., 2007; Zom et al., 2012). Diets primarily included grass silage, fresh grass, dehydrated grass, corn, corn silage, cereal, concentrates or beet pulp. Average DM of the diets was $53 \mathrm{~g} / 100 \mathrm{~g}$. All cows were kept indoors in conventional cubicle housing and they were offered completely mixed diets ad libitum. They were milked twice a day, except for half of the cows in one of the locations $(\mathrm{n}=50)$ that were milked 3 times per day. Recording frequencies of the individual feed-intake-related traits varied by experiment: DMI was recorded 1, 2, 3, or 5 times per week (Veerkamp et al., 2000; Beerda et al., 2007; Zom et al., 2012), whereas BW was measured with weighing platforms 3 times per week or daily.

Additional feed-intake-related traits were calculated: MilkE, MBW, and RFI. A full description of the data editing strategies can be found in Tempelman et al. (2015). Milk energy output is expressed in megacalories and was calculated from weekly MY plus the fat \% $(\mathbf{F P})$, protein \% (PP), and lactose \% (LP), using the following formula according to National Research Dairy Council (2001):

$$
\begin{gathered}
\text { MilkE }=(0.0929 \times \mathrm{FP}+0.0563 \times \mathrm{PP} \\
+0.0395 \times \mathrm{LP}) \times \mathrm{MY} / 100 .
\end{gathered}
$$

Weekly MBW was computed as the weekly average $\mathrm{BW}^{0.75}$. Kleiber (1932) determined MBW to be proportional to the basal metabolic rate of animals and to be representative of maintenance nutrient requirements for animals as a function of their BW. Residual feed intake is defined as the estimated residual from an energy sink model (Berry et al., 2014), whereby weekly DMI was modeled as a linear function of MilkE, MBW, and BW. The following 6 feed-intake-related traits were analyzed: DMI, RFI, MilkE, MY, BW, and MBW. Twenty-eight-day-average traits were calculated based on the records obtained in the first period of $28 \mathrm{~d}$ between 50 and 200 DIM (Tempelman et al., 2015). This restriction was imposed because $\mathrm{BW}$ changes are more stable in this interval, resulting in more robust RFI 
determinations, compared with determinations outside this DIM interval. Data from NL were on weekly basis, and in this case, 4 weekly records were used, taking the first observation after $7 \mathrm{wk}$ in lactation and the following 3 observations to calculate the 28-d average. Only data from the earliest parity of each animal were used, and only cows with at least $75 \%$ of Holstein genes were included. These editing steps resulted in a final data set with 1,665 cows, sired by 372 bulls. A description of the data is shown in Table 1.

United States. Data for MY, DMI, and BW (2,276 records from 1,924 cows) were collected during 2007 to 2013 from 7 different research stations in United States: University of Florida (FL), Iowa State University (ISU), Michigan State University (MSU), the USDA-ARS Forage Research Center in Madison (USDFRC), the University of Wisconsin research herd (UW), Virginia Tech (VT), and the USDA Animal Genomics and Improvement Laboratory (AGIL) in Beltsville, Maryland. Description of the methodology of some experiments and of the content of the diets has been summarized previously [e.g., by Spurlock et al. (2012) and Yao et al. (2013) for ISU, by Ferraretto et al. $(2011,2012)$ and He et al. (2012) for part of the data from UW, and by Potts et al. (2015) for MSU]. The diets included corn silage, legume silage, wheat straw, soybean hulls, cottonseed, corn, and limestone. The average DM of the diets was $50 \mathrm{~g} / 100 \mathrm{~g}$. Dry matter intake and MY were recorded daily in all experiments, and data from a particular lactation were included if at least 28 daily records on both traits were available. Body weight was recorded daily (FL, MSU, UW, and VT), weekly (ISU, MSU, and USDFRC), or every $2 \mathrm{wk}$ (UW), depending on the experiment. Milk components (FP, PP, and LP) were recorded either daily (FL and VT), weekly (ISU, MSU, USDFRC, UW), or every 2 wk (USDFRC). The 6 feed-intake-related traits were derived in the same way as described above for the Dutch data. Averages from 1,921 cows were kept (from 478 sires). A description of the data is provided in Table 1.

\section{Data Collection and Editing: Conformation Traits}

Data on 7 conformation traits were available: stature (ST), CW, body depth (BD), angularity (ANG), rump angle (RA), rump width (RW), and BCS. Linear conformation traits were defined according to the World Holstein Friesian Federation (Holstein Association USA, 2014; WHFF, 2014) and scored (i.e., 1 to 9 in NL, and from 1 to 50 in US). The different scale in both countries implies that the means cannot be compared between the 2 countries. However, the CV of the traits were similar and the trait definition and the

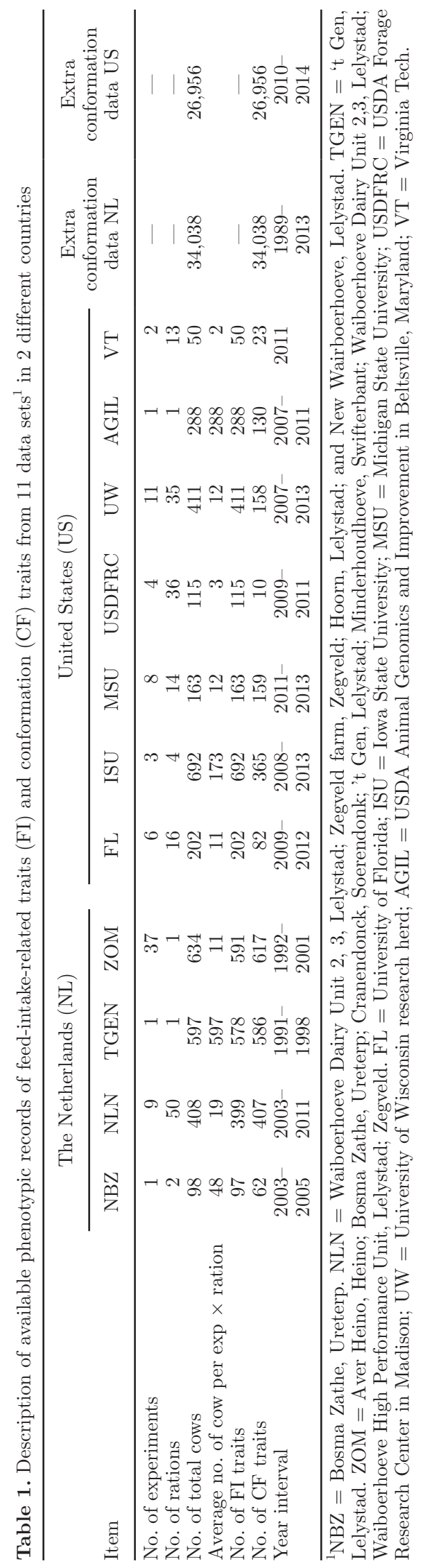

Journal of Dairy Science Vol. 99 No. 1, 2016 
description to score them was visually equivalent for the extreme and intermediate values. For example, CW in NL was scored from narrow (1-3) to intermediate (4-6) to wide (7-9), whereas CW in US was scored from extremely narrow and frail (1-5), to intermediate (25), to extremely strong and wide (45-50; Holstein Association, 2014; WHFF, 2014). Similar, in both countries, $\mathrm{BD}$ is scored from shallow to deep, ANG is scored from lack of angularity to very angular, RA is scored from high pins to extreme slope, RW is scored from narrow to wide, and BCS is scored from poor to grossly fat. In the US, CW is called dairy strength, and ANG is called dairy form. Stature is measured in centimeters minus 100 in NL and classified from 1 to 50 in US going from short to tall.

The Netherlands. Most Dutch cows with feedintake-related information also had conformation recorded (1,603 of 1,665; Table 1). Conformation traits were measured once in the lifetime of the cow, during the first lactation. In most cases, this is close to the time when the nutritional experiment was performed. Conformation traits were recorded between 1989 and 2013.

Additional conformation data of progeny from the 372 sires were extracted from the Dutch national database from CRV (Dutch/Flemish cattle improvement cooperative, Arnhem, the Netherlands). This additional information was used for the bivariate analyses between feed-intake-related and conformation traits within the NL. The criterion to get extra conformation data from Dutch sires was to choose cows from herd-date classification groups with at least 5 cows coming from 5 different sires out of the 372 sires of our data. The final data set included 34,038 extra Dutch cows with conformation data, plus the 1,603 cows with DMI recorded, resulting in a total of 35,641 cows with conformation data.

United States. In total, 2,277 recordings of the 7 conformation traits were available on 927 of the 1,921 cows with feed intake information. Only one conformation record per cow was kept, being the record taken during the nutritional experiments, or the nearest record to the time when feed-intake-related traits were recorded. A summary of the distribution of records at each location is shown in Table 1.

Additional conformation data of progeny from the 478 sires were extracted from the USDA pedigree database. Accepting data with a classification date in 2010 or later resulted in 354,484 records. A second criterion was to select only contemporary groups (herd-year classes) with 200 or more records. This resulted in a total of 68 contemporary groups with records from the 478 sires. Selecting all records from those 68 groups resulted in a total of 32,186 additional conformation records. Even though some US cows had multiple records on conformation traits, only one record per cow was kept for this study. This left a total of 27,883 cows with conformation data, including 927 that also had feed intake information.

\section{Data Collection and Editing: Pedigrees}

The Netherlands. This pedigree was created from 35,641 individuals, of which 35,579 had conformation data and 1,665 had feed intake information. The complete pedigree contained 304,095 individuals, but was further cut at 4 generations, making sure that all sires and dams were identified $(\mathrm{n}=152,314)$. After that, the pedigree was pruned by removing noninformative individuals (i.e., animals without any ancestral ties to phenotypes on other individuals, leaving a total of 144,489 animals in the pedigree).

United States. This pedigree was created from 28,877 individuals, of which 27,883 had conformation data and 1,921 had feed intake information. The full pedigree contained 120,485 individuals but was further cut at 4 generations $(\mathrm{n}=97,140)$. After pruning, 94,405 animals remained.

\section{Statistical Analyses}

Univariate analyses were performed to estimate the variance components and the heritabilities for all 13 traits per country [i.e., 6 feed-intake-related traits (DMI, RFI, MilkE, MY, BW, and MBW) and 7 conformation traits (ST, CW, BD, ANG, RA, RW, and BCS)]. All the analyses were performed using ASReml 4.0 (Gilmour et al., 2009).

The model used for feed-intake-related traits was as follows:

$$
\mathrm{y}=\mu+\mathrm{LER}+\mathrm{PC}\left(\sum_{0}^{2} \beta \mathrm{ACC}\right)+\mathrm{LYS}+\mathrm{DIM}+\mathrm{a}+\mathrm{e} .
$$

Here, y is the phenotype for DMI, RFI, MilkE, MY, $\mathrm{BW}$, or MBW; $\mu$ is the mean; LER is the fixed effect of location $\times$ experiment $\times$ ration; ACC is the fixed regression coefficient for age of cow at calving in months nested in parity class [PC, 2 classes: primiparous $(60 \%$ in NL and $53 \%$ in US) and multiparous]; $\beta$ is the term of the second order Legendre polynomial for ACC; LYS is the fixed effect date of location $\times$ year $\times$ season of measurement; DIM is the fixed effect of the days in milk when the 28-d recording period started; $a$ is the additive genetic random effect of animal, and e is the 
residual term of y. The classes for the fixed effects were 112 classes for LER in NL and 132 in US, with on average 21 and 17 animals per class, respectively, and 83 classes in NL and 115 classes in US had $>1$ cow. Age at calving ranged between 17 and 36 mo in NL, with an average of 26, and between 21 and 127 in US, with an average of 36; LYS had 122 classes in NL and 99 in US, and 118 classes consisted of $>1$ cow in NL and all US classes had $>1$ cow. Days in milk when the recording period started ranged between 61 and 180 in NL, with an average of 31 cows recorded per day; and DIM ranged between 64 and $186 \mathrm{~d}$ in US, with an average of 16 cows recorded per day. In the Netherlands, on $53 \mathrm{~d}$ $>1$ cow was recorded, and in US on $106 \mathrm{~d}>1$ cow was recorded. ASReml accounted for all classes with just 1 cow. Location was specified to interact with experiment and ration, as well as with year and season, to take into account that some experiments lasted for several years (especially in NL).

The model used for conformation traits was

$$
\mathrm{y}=\mu+\mathrm{HDS}+\mathrm{ACC}+\mathrm{ML}+\mathrm{a}+\mathrm{e},
$$

where y is phenotype for $\mathrm{ST}, \mathrm{CW}, \mathrm{BD}, \mathrm{ANG}, \mathrm{RA}, \mathrm{RW}$, and $\mathrm{BCS} ; \mu$ is the mean; HDS is the fixed effect of herd $\times$ classification date $\times$ classification standard for NL (6,585 classes, where classification standard is black and white, red and white, or dual purpose; CRV, 2014), and of herd $\times$ classification date for US (3,402 classes); ACC is the fixed effect of age of cow at classification in months (35 classes in NL and 105 in US); ML is the fixed effect of lactation stage at classification in months ( 26 classes in NL and 83 in US); a is the random additive genetic effect of animal; and e is the residual term of $y$.

Four different sets of bivariate analyses were performed to obtain genetic correlation estimates; 2 sets of bivariate analyses between feed-intake-related traits and conformation traits within a country (42 analyses per country, product of 6 feed-intake-related traits times 7 conformation traits), and 2 sets of bivariate analyses within feed-intake-related traits (15 per country, product of all possible combinations within feedintake-related traits). The estimated parameters from the univariate analyses were used as starting values for the bivariate analyses. Due to the lack of genetic links (4 sires) between the 2 populations, it was not possible to estimate genetic correlations between countries. Therefore, the genetic parameters that were estimated in this study were within each country between feedintake related traits and conformation traits.

To know which combination of conformation traits is the best predictor of feed intake, selection index theory (Falconer and Mackay, 1996) was applied to calculate accuracies of breeding values. For this purpose, the genetic correlations between the conformation traits were estimated as well, using the model described above. Accuracies were calculated for predicting DMI, RFI, and MBW for 2 cases: (1) for cows, when only single phenotypic records are available, and (2) for bulls. The bull case assumes that highly accurate breeding values from bulls are available for all predictors. The following formula was used to calculate the accuracy of the selection index $\left(\mathrm{r}_{\mathrm{HI}}\right)$ :

$$
\mathrm{r}_{\mathrm{HI}}=\frac{\sigma_{\mathrm{HI}}}{\sigma_{\mathrm{I}}^{2} \sigma_{\mathrm{H}}^{2}}=\sqrt{\frac{\mathrm{b}^{\prime} \mathbf{G v}}{\mathrm{v}^{\prime} \mathbf{C v}}} .
$$

where $\sigma_{\mathrm{HI}}$ is the covariance between the breeding goal and the selection index, $\sigma_{\mathrm{I}}^{2}$ is the selection index variance, and $\sigma_{\mathrm{H}}^{2}$ is the breeding goal variance. Here, $\mathrm{b}$ is the index coefficient that is calculated as

$$
\mathrm{b}=\mathbf{P}^{-1} \mathbf{G v},
$$

where $\mathbf{P}$ is the genetic variance-covariance matrix between the predictor traits (for the case of bulls) and the phenotypic variance-covariance matrix between the predictor traits (for the case of cows), $\mathbf{G}$ is the vector of genetic covariances between the predictor traits in the selection index and the breeding goal trait, and $\mathrm{v}$ is the economic value. Because we are only interested in predicting one trait at the time (DMI, RFI, or MBW), the value of $\mathrm{v}$ is set arbitrarily to 1 , which means that all the weight is on one trait, as is the only trait in the breeding goal. Finally, $\mathbf{C}$ is the genetic variancecovariance matrix between the breeding goal trait(s).

\section{RESULTS}

\section{Descriptive Statistics}

Descriptive statistics of feed-intake-related and conformation traits for NL and US are shown in Table 2. The averages for feed-intake-related traits were higher in US compared with NL cows; DMI was $20.7 \mathrm{~kg} / \mathrm{d}$ in NL and $24.1 \mathrm{~kg} / \mathrm{d}$ in US, whereas MY was $33.5 \mathrm{~kg} / \mathrm{d}$ in NL and $42.7 \mathrm{~kg} / \mathrm{d}$ in US, and BW was $575 \mathrm{~kg}$ in NL and $605 \mathrm{~kg}$ in US. The descriptive statistics for conformation traits for NL and US were not comparable with each other because they are expressed using a different scale (NL $=1$ to 9 , except for ST recorded in centimeters, and US $=1$ to 50 for all traits). The averages for the conformation traits in NL were between 4.8 for ANG and 5.2 for BD, and $44 \mathrm{~cm}$ for ST, whereas the averages for US were between 24.6 for RA and 26.9 for $\mathrm{BD}$, and 33 units for ST. 


\section{Genetic Parameters}

Estimated Heritabilities. Estimated genetic variances and heritabilities for all traits for both countries are shown in Table 3. Estimated heritabilities for feedintake-related traits were moderate to high in both countries, varying from 0.18 for MilkE in US to 0.53 for BW and MBW in NL, with all SE ranging between 0.05 and 0.07. Estimated heritabilities for DMI were 0.32 in NL and 0.29 in US. These heritabilities were higher than the estimated heritabilities for RFI (i.e., 0.25 and 0.22 , respectively). Estimated heritabilities for MY and MilkE were higher in NL than in US (i.e., 0.37 and 0.20 for MY, respectively, and 0.26 and 0.18 for MilkE). Finally, heritabilities for BW and MBW were both 0.53 in NL and 0.43 in US.

Because the scale of the conformation traits is different in both countries, the genetic and residual variances cannot be compared. However, in general, the heritabilities were higher in NL than in US. The heritabilities were within the range of 0.28 for $\mathrm{CW}$ and 0.60 for ST in NL and between 0.17 for BCS and 0.40 for ST in US; in both countries the SE were 0.02 for all traits.

\section{Correlations Within Feed-Intake-Related Traits}

Genetic and phenotypic correlations within feedintake-related traits for both countries are presented in Table 4. Dry matter intake was genetically and phenotypically high correlated with RFI in both countries (0.70 and 0.72 , respectively, for NL, and 0.89 and 0.69 for US). This was expected, given that the RFI is the residual of DMI after adjusting for the energy sinks (MilkE and MBW). The genetic correlation between DMI and MY was, in both countries, lower than the correlation between DMI and MilkE. The genetic and phenotypic correlation of BW and MBW with DMI was the same in US (0.46), and almost the same in NL (0.55 and 0.56$)$.

Residual feed intake was expected to have a zero phenotypic correlation with energy sinks, as it is feed intake adjusted for those energy sinks. This is also observed, and RFI also showed, in both countries, phenotypic correlations close to zero with MilkE, MY, BW, and MBW. Contrary, the genetic correlations between RFI and MilkE, MY, BW, and MBW were different from zero, especially in US, ranging between 0.26 and 0.40 .

Based on the heritabilities and genetic correlations (Table 4), BW and MBW seem to have the same genetic background, which was expected because the transformation becomes close to linear within the scale of BW, even though MBW is a nonlinear transformation of BW. 
Table 3. Estimated genetic $\left(\sigma_{a}^{2}\right)$ and error $\left(\sigma_{e}^{2}\right)$ variances, and heritabilities $\left(\mathrm{h}^{2}\right)$ with the corresponding standard error from univariate analyses per trait and per country

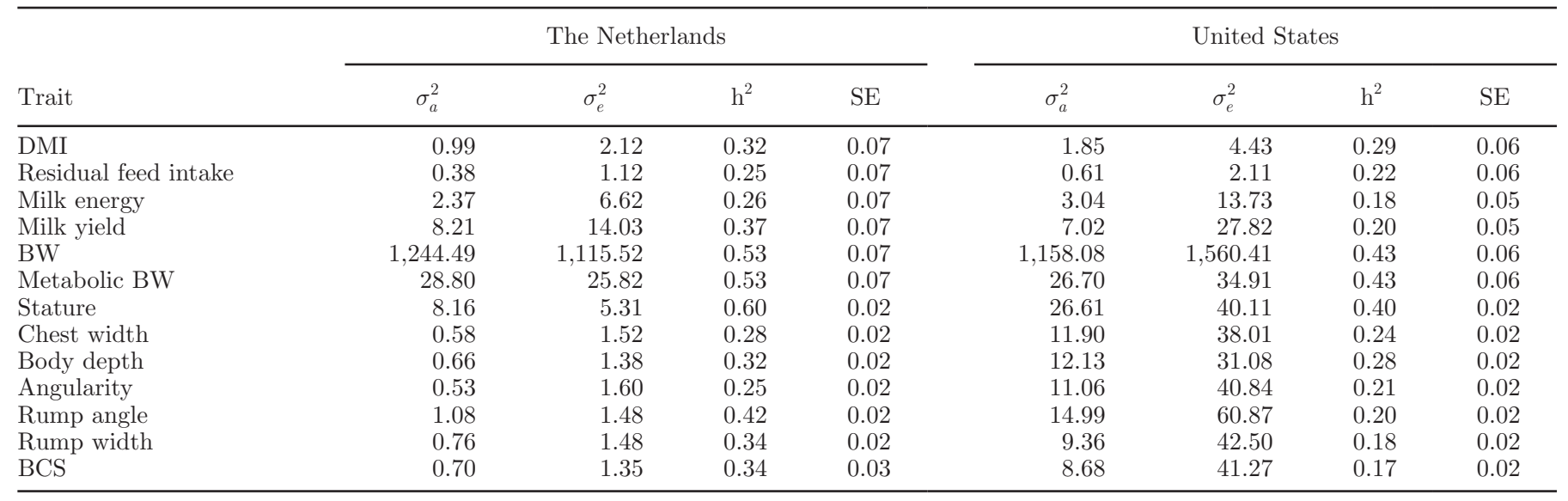

\section{Correlations Between Feed-Intake-Related Traits and Conformation Traits in NL}

Genetic and phenotypic correlations between feed-intake-related traits and conformation traits in NL, with their respective SE, are shown in Table 5. The highest positive genetic correlation between DMI and the conformation traits was estimated between DMI and CW (0.45), and the phenotypic correlation between those 2 traits was 0.15 . For all other conformation traits, the estimated genetic correlations with DMI ranged between -0.02 (ANG) and 0.33 (ST), and the phenotypic correlations ranged between $0.01(\mathrm{RA})$ and 0.20 (ST).

The highest positive correlation between RFI and conformation traits was estimated between RFI and ANG (0.13 for genetic and 0.05 for phenotypic), and the strongest negative correlation was estimated with BCS ( -0.24 for genetic and -0.09 for phenotypic).
For MY and MilkE, the highest positive correlation was estimated with ANG (genetic and phenotypic correlation was 0.47 and 0.17 , respectively, for MY; and 0.33 and 0.17 for MilkE). Conversely, slightly negative genetic correlations were estimated between MY and CW (-0.04) and between MilkE and RW (-0.07). Finally, BW and MBW were highly positively correlated with CW (0.78 for genetic and 0.45 for phenotypic) and BCS (0.83 and 0.45 for genetic and phenotypic, respectively).

\section{Correlations Between Feed-Intake-Related Traits and Conformation Traits in US}

Estimated genetic and phenotypic correlations between feed-intake-related traits and conformation traits in US with their respective SE are presented in Table 6. Estimated genetic correlations of DMI with the con-

Table 4. Genetic (above diagonal) and phenotypic (below diagonal) correlations between feed-intake-related traits ${ }^{1}$ in the Netherlands (NL) and the United States (US), with the corresponding standard errors in parentheses

\begin{tabular}{|c|c|c|c|c|c|c|c|c|c|c|c|c|}
\hline Trait & \multicolumn{6}{|c|}{ NL } & \multicolumn{6}{|c|}{ US } \\
\hline DMI & & $\begin{array}{c}0.70 \\
(0.09)\end{array}$ & $\begin{array}{c}0.63 \\
(0.12)\end{array}$ & $\begin{array}{c}0.44 \\
(0.13)\end{array}$ & $\begin{array}{c}0.55 \\
(0.10)\end{array}$ & $\begin{array}{c}0.56 \\
(0.10)\end{array}$ & & $\begin{array}{c}0.89 \\
(0.06)\end{array}$ & $\begin{array}{c}0.63 \\
(0.11)\end{array}$ & $\begin{array}{c}0.36 \\
(0.15)\end{array}$ & $\begin{array}{c}0.46 \\
(0.11)\end{array}$ & $\begin{array}{c}0.46 \\
(0.11)\end{array}$ \\
\hline RFI & $\begin{array}{c}0.72 \\
(0.01)\end{array}$ & & $\begin{array}{c}0.12 \\
(0.20)\end{array}$ & $\begin{array}{c}0.11 \\
(0.17)\end{array}$ & $\begin{array}{c}0.04 \\
(0.16)\end{array}$ & $\begin{array}{c}0.05 \\
(0.16)\end{array}$ & $\begin{array}{c}0.69 \\
(0.01)\end{array}$ & & $\begin{array}{c}0.40 \\
(0.19)\end{array}$ & $\begin{array}{c}0.35 \\
(0.19)\end{array}$ & $\begin{array}{c}0.26 \\
(0.16)\end{array}$ & $\begin{array}{c}0.26 \\
(0.16)\end{array}$ \\
\hline MilkE & $\begin{array}{c}0.57 \\
(0.02)\end{array}$ & $\begin{array}{c}0.02 \\
(0.03)\end{array}$ & & $\begin{array}{c}0.76 \\
(0.06)\end{array}$ & $\begin{array}{c}0.19 \\
(0.15)\end{array}$ & $\begin{array}{c}0.19 \\
(0.15)\end{array}$ & $\begin{array}{c}0.63 \\
(0.01)\end{array}$ & $\begin{array}{c}0.02 \\
(0.03)\end{array}$ & & $\begin{array}{c}0.59 \\
(0.12)\end{array}$ & $\begin{array}{c}-0.14 \\
(0.16)\end{array}$ & $\begin{array}{r}-0.13 \\
(0.16)\end{array}$ \\
\hline BW & $\begin{array}{c}0.45 \\
(0.02)\end{array}$ & $\begin{array}{c}0.02 \\
(0.03)\end{array}$ & $\begin{array}{c}0.21 \\
(0.03)\end{array}$ & $\begin{array}{c}0.09 \\
(0.03)\end{array}$ & & $\begin{array}{c}0.99 \\
(0.00)\end{array}$ & $\begin{array}{c}0.42 \\
(0.02)\end{array}$ & $\begin{array}{c}0.01 \\
(0.03)\end{array}$ & $\begin{array}{c}0.16 \\
(0.03)\end{array}$ & $\begin{array}{c}0.09 \\
(0.03)\end{array}$ & & $\mathrm{NE}^{2}$ \\
\hline MBW & $\begin{array}{c}0.45 \\
(0.02)\end{array}$ & $\begin{array}{c}0.02 \\
(0.03)\end{array}$ & $\begin{array}{c}0.21 \\
(0.03)\end{array}$ & $\begin{array}{c}0.09 \\
(0.03)\end{array}$ & $\begin{array}{c}0.99 \\
(0.00)\end{array}$ & & $\begin{array}{c}0.42 \\
(0.02)\end{array}$ & $\begin{array}{c}0.01 \\
(0.03)\end{array}$ & $\begin{array}{c}0.16 \\
(0.03)\end{array}$ & $\begin{array}{c}0.10 \\
(0.03)\end{array}$ & $\mathrm{NE}$ & \\
\hline
\end{tabular}

${ }^{1}$ Feed-intake-related traits: RFI $=$ residual feed intake; MilkE $=$ milk energy; $\mathrm{MY}=$ milk yield. $\mathrm{MBW}=$ metabolic body weight.

${ }^{2} \mathrm{NE}=$ not estimable. 
Table 5. Genetic correlations and phenotypic correlations between feed-intake-related traits ${ }^{1}$ and conformation traits ${ }^{2}$ in the Netherlands, with the corresponding standard errors in parentheses

\begin{tabular}{|c|c|c|c|c|c|c|c|c|c|c|c|c|c|c|}
\hline \multirow[b]{2}{*}{ Trait } & \multicolumn{7}{|c|}{ Genetic correlation } & \multicolumn{7}{|c|}{ Phenotypic correlation } \\
\hline & ST & $\mathrm{CW}$ & $\mathrm{BD}$ & ANG & $\mathrm{RA}$ & RW & BCS & ST & $\mathrm{CW}$ & $\mathrm{BD}$ & ANG & RA & RW & $\mathrm{BCS}$ \\
\hline$\overline{\mathrm{DMI}}$ & 0.33 & 0.45 & $\begin{array}{c}0.26 \\
(0.12)\end{array}$ & $\begin{array}{c}-0.02 \\
(0.15)\end{array}$ & $\begin{array}{c}0.10 \\
(0.11)\end{array}$ & $\begin{array}{c}0.04 \\
(0.12)\end{array}$ & $\begin{array}{c}0.24 \\
(0.14)\end{array}$ & $\begin{array}{c}0.20 \\
(0.03)\end{array}$ & $\begin{array}{c}0.15 \\
(0.03)\end{array}$ & $\begin{array}{c}0.18 \\
(0.03)\end{array}$ & $\begin{array}{c}0.04 \\
(0.03)\end{array}$ & $\begin{array}{c}0.01 \\
(0.03)\end{array}$ & $\begin{array}{c}0.06 \\
(0.03)\end{array}$ & $\begin{array}{c}0.06 \\
(0.04)\end{array}$ \\
\hline RFI & $\begin{array}{c}0.12 \\
(0.12)\end{array}$ & $\begin{array}{c}(0.06) \\
0.15)\end{array}$ & $\begin{array}{c}0.12) \\
(0.13)\end{array}$ & $\begin{array}{c}(0.13) \\
0.13 \\
(0.16)\end{array}$ & $\begin{array}{c}(0.11) \\
-0.07 \\
(0.12)\end{array}$ & $\begin{array}{c}(0.12) \\
-0.06 \\
(0.13)\end{array}$ & $\begin{array}{c}(0.14) \\
-0.24 \\
(0.15)\end{array}$ & $\begin{array}{c}0.03) \\
0.03 \\
(0.03)\end{array}$ & $\begin{array}{c}(0.03) \\
-0.03 \\
(0.03)\end{array}$ & $\begin{array}{c}(0.00) \\
0.06 \\
(0.03)\end{array}$ & $\begin{array}{c}(0.03) \\
0.05 \\
(0.03)\end{array}$ & $\begin{array}{c}(0.0 .01) \\
-0.01 \\
(0.03)\end{array}$ & $\begin{array}{c}(0.05) \\
(0.03)\end{array}$ & $\begin{array}{r}-0.09 \\
(0.04)\end{array}$ \\
\hline MilkE & $\begin{array}{c}0.06 \\
(0.12)\end{array}$ & $\begin{array}{c}0.09 \\
(0.15)\end{array}$ & $\begin{array}{c}0.12 \\
(0.13)\end{array}$ & $\begin{array}{c}0.33 \\
(0.15)\end{array}$ & $\begin{array}{c}0.25 \\
(0.12)\end{array}$ & $\begin{array}{c}-0.07 \\
(0.13)\end{array}$ & $\begin{array}{c}-0.05 \\
(0.16)\end{array}$ & $\begin{array}{c}0.08 \\
(0.03)\end{array}$ & $\begin{array}{c}0.02 \\
(0.03)\end{array}$ & $\begin{array}{c}0.11 \\
(0.03)\end{array}$ & $\begin{array}{c}0.17 \\
(0.03)\end{array}$ & $\begin{array}{c}0.06 \\
(0.03)\end{array}$ & $\begin{array}{c}0.08 \\
(0.03)\end{array}$ & $\begin{array}{r}-0.05 \\
(0.04)\end{array}$ \\
\hline MY & $\begin{array}{c}0.09 \\
(0.10)\end{array}$ & $\begin{array}{c}-0.04 \\
(0.13)\end{array}$ & $\begin{array}{c}0.03 \\
(0.11)\end{array}$ & $\begin{array}{c}0.47 \\
(0.12)\end{array}$ & $\begin{array}{c}0.17 \\
(0.10)\end{array}$ & $\begin{array}{c}0.00 \\
(0.11)\end{array}$ & $\begin{array}{c}-0.31 \\
(0.13)\end{array}$ & $\begin{array}{c}0.08 \\
(0.03)\end{array}$ & $\begin{array}{r}-0.03 \\
(0.03)\end{array}$ & $\begin{array}{c}0.08 \\
(0.03)\end{array}$ & $\begin{array}{c}0.17 \\
(0.03)\end{array}$ & $\begin{array}{c}0.04 \\
(0.03)\end{array}$ & $\begin{array}{c}0.09 \\
(0.03)\end{array}$ & $\begin{array}{r}-0.10 \\
(0.04)\end{array}$ \\
\hline BW & $\begin{array}{c}0.50 \\
(0.07)\end{array}$ & $\begin{array}{c}0.77 \\
(0.07)\end{array}$ & $\begin{array}{c}0.45 \\
(0.08)\end{array}$ & $\begin{array}{c}-0.43 \\
(0.11)\end{array}$ & $\begin{array}{c}0.05 \\
(0.09)\end{array}$ & $\begin{array}{c}0.26 \\
(0.09)\end{array}$ & $\begin{array}{c}0.83 \\
(0.07)\end{array}$ & $\begin{array}{c}0.40 \\
(0.02)\end{array}$ & $\begin{array}{c}0.45 \\
(0.03)\end{array}$ & $\begin{array}{c}0.26 \\
(0.03)\end{array}$ & $\begin{array}{c}-0.12 \\
(0.03)\end{array}$ & $\begin{array}{c}-0.03 \\
(0.03)\end{array}$ & $\begin{array}{c}0.22 \\
(0.03)\end{array}$ & $\begin{array}{c}0.45 \\
(0.03)\end{array}$ \\
\hline MBW & $\begin{array}{c}0.50 \\
(0.07)\end{array}$ & $\begin{array}{c}0.78 \\
(0.07)\end{array}$ & $\begin{array}{c}0.45 \\
(0.08)\end{array}$ & $\begin{array}{r}-0.43 \\
(0.11)\end{array}$ & $\begin{array}{c}0.06 \\
(0.09)\end{array}$ & $\begin{array}{c}0.26 \\
(0.09)\end{array}$ & $\begin{array}{c}0.83 \\
(0.07)\end{array}$ & $\begin{array}{c}0.41 \\
(0.02)\end{array}$ & $\begin{array}{c}0.46 \\
(0.02)\end{array}$ & $\begin{array}{c}0.26 \\
(0.02)\end{array}$ & $\begin{array}{c}-0.21 \\
(0.03)\end{array}$ & $\begin{array}{r}-0.03 \\
(0.03)\end{array}$ & $\begin{array}{c}0.22 \\
(0.03)\end{array}$ & $\begin{array}{c}0.46 \\
(0.03)\end{array}$ \\
\hline
\end{tabular}

${ }^{1}$ Feed-intake-related traits: $\mathrm{RFI}=$ residual feed intake; MilkE $=$ milk energy; $\mathrm{MY}=$ milk yield; $\mathrm{MBW}=$ metabolic $\mathrm{BW}$.

${ }^{2}$ Conformation traits: $\mathrm{ST}=$ stature; $\mathrm{CW}=$ chest width; $\mathrm{BD}=$ body depth; $\mathrm{ANG}=$ angularity; $\mathrm{RA}=$ rump angle; $\mathrm{RW}=$ rump width .

Table 6. Genetic correlations and phenotypic correlations between feed-intake-related traits ${ }^{1}$ and conformation traits ${ }^{2}$ in the United States, with the corresponding standard error in parentheses

Genetic correlation

Phenotypic correlation

\begin{tabular}{|c|c|c|c|c|c|c|c|c|c|c|c|c|c|c|}
\hline Trait & $\mathrm{ST}$ & $\mathrm{CW}$ & $\mathrm{BD}$ & ANG & $\mathrm{RA}$ & RW & BCS & $\mathrm{ST}$ & $\mathrm{CW}$ & $\mathrm{BD}$ & ANG & $\mathrm{RA}$ & RW & BCS \\
\hline$\overline{\mathrm{DMI}}$ & $\begin{array}{c}0.57 \\
(0.11)\end{array}$ & $\begin{array}{c}0.61 \\
(0.12)\end{array}$ & $\begin{array}{c}0.49 \\
(0.12)\end{array}$ & $\begin{array}{c}0.15 \\
(0.14)\end{array}$ & $\begin{array}{c}0.21 \\
(0.15)\end{array}$ & $\begin{array}{c}0.13 \\
(0.15)\end{array}$ & $\begin{array}{c}0.46 \\
(0.15)\end{array}$ & $\begin{array}{c}0.22 \\
(0.04)\end{array}$ & $\begin{array}{c}0.25 \\
(0.03)\end{array}$ & $\begin{array}{c}0.28 \\
(0.03)\end{array}$ & $\begin{array}{c}0.13 \\
(0.03)\end{array}$ & $\begin{array}{c}0.03 \\
(0.04)\end{array}$ & $\begin{array}{c}0.12 \\
(0.04)\end{array}$ & $\begin{array}{c}0.08 \\
(0.04)\end{array}$ \\
\hline RFI & $\begin{array}{c}0.43 \\
(0.14)\end{array}$ & $\begin{array}{c}0.21 \\
(0.16)\end{array}$ & $\begin{array}{c}0.10 \\
(0.15)\end{array}$ & $\begin{array}{c}0.08 \\
(0.16)\end{array}$ & $\begin{array}{c}-0.06 \\
(0.16)\end{array}$ & $\begin{array}{c}-0.02 \\
(0.17)\end{array}$ & $\begin{array}{c}0.14 \\
(0.17)\end{array}$ & $\begin{array}{c}0.06 \\
(0.04)\end{array}$ & $\begin{array}{c}0.08 \\
(0.04)\end{array}$ & $\begin{array}{c}0.10 \\
(0.04)\end{array}$ & $\begin{array}{c}0.06 \\
(0.04)\end{array}$ & $\begin{array}{c}0.00 \\
(0.04)\end{array}$ & $\begin{array}{c}0.03 \\
(0.04)\end{array}$ & $\begin{array}{c}0.02 \\
(0.04)\end{array}$ \\
\hline MilkE & $\begin{array}{c}0.15 \\
(0.16)\end{array}$ & $\begin{array}{c}0.33 \\
(0.18)\end{array}$ & $\begin{array}{c}0.45 \\
(0.16)\end{array}$ & $\begin{array}{c}0.36 \\
(0.16)\end{array}$ & $\begin{array}{c}0.35 \\
(0.17)\end{array}$ & $\begin{array}{c}-0.08 \\
(0.18)\end{array}$ & $\begin{array}{c}0.03 \\
(0.19)\end{array}$ & $\begin{array}{c}0.04 \\
(0.04)\end{array}$ & $\begin{array}{c}0.02 \\
(0.04)\end{array}$ & $\begin{array}{c}0.11 \\
(0.04)\end{array}$ & $\begin{array}{c}0.19 \\
(0.03)\end{array}$ & $\begin{array}{c}0.04 \\
(0.04)\end{array}$ & $\begin{array}{c}0.03 \\
(0.04)\end{array}$ & $\begin{array}{c}-0.08 \\
(0.04)\end{array}$ \\
\hline MY & $\begin{array}{c}0.18 \\
(0.15)\end{array}$ & $\begin{array}{c}0.18 \\
(0.17)\end{array}$ & $\begin{array}{c}0.39 \\
(0.16)\end{array}$ & $\begin{array}{c}0.48 \\
(0.15)\end{array}$ & $\begin{array}{c}0.39 \\
(0.16)\end{array}$ & $\begin{array}{c}0.13 \\
(0.17)\end{array}$ & $\begin{array}{c}-0.07 \\
(0.18)\end{array}$ & $\begin{array}{c}0.04 \\
(0.04)\end{array}$ & $\begin{array}{c}0.00 \\
(0.04)\end{array}$ & $\begin{array}{c}0.07 \\
(0.04)\end{array}$ & $\begin{array}{c}0.17 \\
(0.03)\end{array}$ & $\begin{array}{c}0.05 \\
(0.04)\end{array}$ & $\begin{array}{c}0.04 \\
(0.04)\end{array}$ & $\begin{array}{c}-0.07 \\
(0.04)\end{array}$ \\
\hline BW & $\begin{array}{c}0.56 \\
(0.09)\end{array}$ & $\begin{array}{c}0.84 \\
(0.07)\end{array}$ & $\begin{array}{c}0.56 \\
(0.10)\end{array}$ & $\begin{array}{c}-0.18 \\
(0.13)\end{array}$ & $\begin{array}{c}0.03 \\
(0.13)\end{array}$ & $\begin{array}{c}0.42 \\
(0.12)\end{array}$ & $\begin{array}{c}0.85 \\
(0.08)\end{array}$ & $\begin{array}{c}0.40 \\
(0.03)\end{array}$ & $\begin{array}{c}0.45 \\
(0.03)\end{array}$ & $\begin{array}{c}0.36 \\
(0.03)\end{array}$ & $\begin{array}{c}-0.07 \\
(0.03)\end{array}$ & $\begin{array}{c}0.00 \\
(0.03)\end{array}$ & $\begin{array}{c}0.20 \\
(0.03)\end{array}$ & $\begin{array}{c}0.31 \\
(0.03)\end{array}$ \\
\hline MBW & $\begin{array}{c}0.56 \\
(0.09)\end{array}$ & $\begin{array}{c}0.84 \\
(0.07)\end{array}$ & $\begin{array}{c}0.56 \\
(0.10)\end{array}$ & $\begin{array}{c}-0.17 \\
(0.13)\end{array}$ & $\begin{array}{c}0.03 \\
(0.13)\end{array}$ & $\begin{array}{c}0.43 \\
(0.12)\end{array}$ & $\begin{array}{c}0.85 \\
(0.08)\end{array}$ & $\begin{array}{c}0.40 \\
(0.03)\end{array}$ & $\begin{array}{c}0.45 \\
(0.03)\end{array}$ & $\begin{array}{c}0.36 \\
(0.03)\end{array}$ & $\begin{array}{c}-0.07 \\
(0.03)\end{array}$ & $\begin{array}{c}0.00 \\
(0.03)\end{array}$ & $\begin{array}{c}0.20 \\
(0.03)\end{array}$ & $\begin{array}{c}0.31 \\
(0.03)\end{array}$ \\
\hline
\end{tabular}

${ }^{1}$ Feed-intake-related traits: RFI $=$ residual feed intake; MilkE $=$ milk energy; MY = milk yield; MBW = metabolic BW.

${ }^{2}$ Conformation traits: $\mathrm{ST}=$ stature; $\mathrm{CW}=$ chest width $\mathrm{BD}=$ body depth; $\mathrm{ANG}=$ angularity; $\mathrm{RA}=$ rump angle; RW = rump width 
formation traits ranged from 0.13 for RW to 0.61 for CW. Similar to the Dutch data, the highest positive genetic correlation for DMI with conformation in US was estimated with CW (0.61, compared with 0.45 in NL; Table 5). The phenotypic correlation between DMI and all the conformation traits ranged between 0.03 (RA) and $0.28(\mathrm{BD})$.

Estimated genetic correlations between RFI and the conformation traits ranged from -0.02 with RW and 0.43 for ST. The estimated genetic correlation between RFI and CW was 0.21 in US (and 0.06 in NL; Table 5). This is lower than the genetic correlation between DMI and CW in both countries. For MilkE the highest estimated genetic correlation was with $\mathrm{BD}(0.45)$, whereas for MY the highest estimated genetic correlation was with ANG (0.48). Finally, BW (and MBW) had the highest estimated genetic correlations with $\mathrm{CW}(0.84)$ and BCS (0.85); this was similar to the genetic correlations estimated in NL between those traits (Table 5). Body weight had a negative genetic correlation $(-0.18)$ estimated with ANG in US, albeit closer to zero than in NL $(-0.43)$.

\section{Selection Index}

Based on the estimated parameters between feedintake-related and conformation traits, several selection indices were used to predict DMI, RFI, and MBW (Table 7). Using a combination of type traits (ST, CW, and $\mathrm{BD})$, DMI was predicted for bulls with accuracies up to 0.43 in NL and 0.64 in US. When MilkE was added to the selection index, the accuracies increased to 0.74 in NL and 0.95 in US. Finally, when BW was also added to the index, the accuracies increased up to 0.79 in NL and 0.97 in US. These accuracies can be obtained when assuming that the genetic parameters are estimated without error.

Predicting RFI was not as accurate in NL as DMI could be predicted. The maximum accuracy was 0.17 for the combination of BW, MilkE, ST, CW, and BD. In US a much higher accuracy of 0.97 was obtained. The difference in accuracies between NL and US is likely due to the low genetic correlations between RFI and all the predictor traits in NL compared with US. For example, the correlation between RFI and MilkE was 0.12 in NL and 0.40 in US, and the correlation between RFI and BW was 0.04 in NL and 0.26 in US. Similar comparisons can be made with the correlations involving RFI with ST, CW, and BD.

\section{DISCUSSION}

The objective of this study was to estimate genetic correlations among 6 feed-intake-related traits and 7 conformation traits within cow populations from the NL and US, to determine if the correlations were different between the 2 countries and to analyze if these conformation traits have large enough heritabilities and genetic correlations to use them as predictors for feedintake-related traits.

Table 7. Accuracies of prediction of DMI, residual feed intake (RFI), and metabolic BW (MBW) using different traits ${ }^{1}$ and their combination in 2 different scenarios, for cows, when just one phenotypic record is available, and for bulls, assuming that highly accurate breeding values are available for all predictors by country [the Netherlands (NL) and the United States (US)]

\begin{tabular}{|c|c|c|c|c|}
\hline \multirow[b]{2}{*}{ Predictor trait } & \multicolumn{2}{|c|}{ NL } & \multicolumn{2}{|c|}{ US } \\
\hline & Bulls & Cows & Bulls & Cows \\
\hline \multicolumn{5}{|l|}{ For DMI } \\
\hline MilkE & 0.64 & 0.33 & 0.63 & 0.26 \\
\hline $\mathrm{BW}$ & 0.58 & 0.42 & 0.47 & 0.30 \\
\hline $\mathrm{ST}, \mathrm{CW}, \mathrm{BD}$ & 0.43 & 0.32 & 0.64 & 0.38 \\
\hline MilkE + ST, CW, BD & 0.74 & 0.36 & 0.95 & 0.46 \\
\hline $\mathrm{BW}+$ MilkE + ST, CW, BD & 0.79 & 0.50 & 0.97 & 0.48 \\
\hline \multicolumn{5}{|l|}{ For RFI } \\
\hline MilkE & 0.12 & 0.06 & 0.42 & 0.18 \\
\hline BW & 0.04 & 0.03 & 0.26 & 0.17 \\
\hline ST, CW, BD & 0.12 & 0.09 & 0.55 & 0.30 \\
\hline MilkE + ST, CW, BD & 0.16 & 0.11 & 0.85 & 0.35 \\
\hline $\mathrm{BW}+$ MilkE + ST, CW, BD & 0.17 & 0.11 & 0.96 & 0.36 \\
\hline \multicolumn{5}{|l|}{ For MBW } \\
\hline ST, CW, BD & 0.85 & 0.50 & 0.95 & 0.46 \\
\hline $\mathrm{BCS}$ & 0.83 & 0.48 & 0.86 & 0.36 \\
\hline ST, CW, BCS & 0.98 & 0.60 & 0.92 & 0.46 \\
\hline $\mathrm{ST}, \mathrm{CW}, \mathrm{BD}, \mathrm{BCS}$ & 0.98 & 0.60 & 0.96 & 0.50 \\
\hline
\end{tabular}

${ }^{1}$ MilkE $=$ milk energy output; $\mathrm{ST}=$ stature $\mathrm{CW}=$ chest width; $\mathrm{BD}=$ body depth. 
Many previous studies have estimated the genetic correlation between conformation traits and milk production traits, BW, fertility traits, or longevity (Harris et al., 1992; Short and Lawlor, 1992; Brotherstone, 1994; Visscher and Goddard, 1995; Van Dorp et al., 1998; Berry et al., 2003a; Brotherstone et al., 2007; de la Fuente et al., 2011). Relatively few studies are available that link conformation traits and feed intake (Veerkamp et al., 1994; Veerkamp and Brotherstone, 1997), and comparisons between countries are nonexistent.

\section{Mean Differences Between US and NL}

Feed-Intake-Related Traits. The means of DMI, $\mathrm{MY}$, and BW were higher in US than in NL; in other words, cows in US are bigger, eat more, and therefore produce more milk. One of the experiments in NL included low-energy rations, and even though this experiment involved only 50 animals, this could have contributed to the lower mean MY and DMI in NL in comparison with US. Perhaps one explanation for the higher MY, DMI, and BW in US compared with NL is that the Dutch data were generally older compared with US data. During the last $25 \mathrm{yr}$, total milk production per cow per year has increased $\sim 50 \%$ in US (USDA, 2015), and therefore, it is likely that feed intake and BW have also increased. In comparison, the total milk production per year per Dutch cow has increased by $35 \%$ in the past $25 \mathrm{yr}$ (CRV, 2014). Therefore, any country comparisons to be surmised from this study are partly confounded with genetic differences because of time trends in selection responses. Furthermore, the differences observed in DMI and MY between countries can be influenced by overall mean diet composition differences. Despite the differences in the phenotypic means between NL and US, the CV of the traits were similar in both countries (i.e., 0.15 and 0.16 for DMI in NL and US, respectively; 0.23 and 0.20 , respectively, for $\mathrm{MY}$ and 0.13 for BW in both countries).

The average RFI was similar in both countries $(-0.01$ in NL and -0.02 in US), suggesting that on average the cows eat as much as is predicted to be needed for its maintenance and milk production. This was expected given that by definition the estimated residuals (RFI) should be zero. However, RFI was calculated separately for each location using separate regressions on the energy sinks (Tempelman et al., 2015). This was done to account for different diet composition across locations and experiments. The consequence of this calculation method is that RFI is expected to average zero within each location. Therefore, the average of location per country should also be zero.
The means of all conformation traits in NL, except ST, are close to 5 , as suggested for linear type traits by Veerkamp et al. (2002), with a standard deviation of 1.6. These means for conformation traits in NL were within the range (4.58 to 6.06) previously reported by Brotherstone (1994), Kadarmideen and Wegmann (2003), Berry et al. (2004), and Zink et al. (2011). Moreover, the means of conformation traits in US were similar to those reported by Short and Lawlor (1992) and Tsuruta et al. (2005) that varied from 22.0 to 28.5 for all the traits.

\section{Variances and Heritabilities in NL and US}

Feed-Intake-Related Traits. The genetic variances for DMI, RFI, and MilkE were slightly larger in US than in NL, whereas the residual variances for DMI and RFI were 2 times larger in US than in NL, and around 4 times larger for MilkE and MY. This resulted in lower heritabilities in US than in NL for most feed-intakerelated traits. The exceptions were BW and MBW in US that had residual variances only $30 \%$ larger than the genetic variances.

The estimated genetic SD of DMI is almost twice as large in US $(1.85 \mathrm{~kg} / \mathrm{d})$ than in NL $(1 \mathrm{~kg} / \mathrm{d})$. The coefficient of genetic variation (ratio between genetic standard deviation and mean) was similar in both countries for DMI (0.05 in NL and 0.06 in US) and MY (0.08 and 0.06 , respectively). So, substantial genetic variation is present in DMI. After adjusting for the energy sinks (to derive RFI), $38 \%$ of the genetic variation was left in NL, and $33 \%$ in US. Thus, although the absolute genetic variance is larger in US, the ratio between the genetic variance of DMI and of RFI is similar in both countries $(\sim 3: 1)$. Estimated heritability of DMI was 0.32 in NL and 0.29 in US, well within the range (0.17 to 0.56$)$ published in the literature as reviewed by Berry and Crowley (2013). Estimated heritabilities for RFI were 0.25 in NL and 0.22 in US, and they were also in the range reported by Veerkamp et al. (1995), who reported heritabilities for RFI between 0.01 and 0.69 including phenotypically and genetically calculated RFI.

The lower heritabilities for feed-intake-related traits in US compared with NL can be due to some missing information in the fixed effects in the model or due to random noise in the measurement of the traits given that the US data cover only $1 / 5$ of the length of the Dutch data collection. The higher heritabilities in NL were seemingly caused by smaller estimated residual variances, because the experiments in NL lasted for $20 \mathrm{yr}$ and the methodology in the measurement of the traits was already standardized, which reduced the residual variance. 
The estimated genetic variances and heritabilities of MY were in the range reported in the literature (Veerkamp, 1998; Berry et al., 2003b; Kadarmideen and Wegmann, 2003; Muller et al., 2006; Nixon et al., 2009; Liinamo et al., 2012). The estimated heritabilities for BW were also in the range of literature from 0.43 to 0.65 (Veerkamp and Brotherstone, 1997; Koenen and Veerkamp, 1998; Berry et al., 2003b; Muller et al., 2006; Dechow et al., 2010). However, comparing heritability estimates across these studies is tricky. For example, in this study, the average of observations from $28 \mathrm{~d}$ was used, whereas other studies might have averages across fewer records or even more. Also, previous studies (Koenen and Veerkamp, 1998; Manzanilla-Pech et al., 2014; Tempelman et al., 2015) have shown that genetic parameters of feed-intake-related traits vary depending on the stage of lactation. Therefore, it is also important to take the lactation stage of recording into account when comparing across studies.

Conformation Traits. Heritabilities and genetic correlations for conformation traits within and between countries (CRV, 2014; Holstein Association USA, 2014; Interbull, 2014) are shown in Table 8. Most of the estimated heritabilities for conformation traits in NL were slightly higher than the reported national heritabilities from CRV (CRV, 2014), except for RW, which was lower in this study, and for ANG where the estimated heritability was twice as large in this study. This can be due to changes in the definition of ANG, which changed in 2008 in the Netherlands (CRV, 2014), noting that more than $66 \%$ of the records on ANG in this study are from before 2008. The heritabilities estimated in this study for the Dutch conformation traits were also slightly higher than the heritabilities estimated by Veerkamp and Brotherstone (1997) that ranged from 0.23 (RW) to 0.50 (ST).

The estimated heritabilities for conformation traits in US were lower in this study than those reported by
Holstein Association USA (2014). Furthermore, Short and Lawlor (1992) estimated lower heritabilities for ST and CW compared with this study, a similar heritability for BD, and higher heritabilities for RA and RW. However, their study was conducted 15 to 20 yr before our study, and the genetic structure of the population could change such that it may have an effect on the estimation of the heritabilities.

Correlations Between Feed-Intake-Related Traits. Genetic correlation between DMI and RFI was high and positive in both countries (0.70 in NL and 0.89 in US). Kennedy et al. (1993) demonstrated how the genetic parameters for RFI can be predicted from the genetic parameters for the underlying traits. These authors predicted a correlation of 0.75 between RFI and DMI, based on heritabilities of 0.3 for DMI and production, a genetic and residual correlation of both 0.5 between DMI and production. This predicted correlation of 0.75 is close to the estimated correlation in our study (e.g., 0.70 in NL and 0.89 in US). Similarly, these authors suggested that when RFI was phenotypically adjusted for the underlying traits, genetic correlations might still exist. This was also observed in the current study, and also by Veerkamp et al. (1995). The genetic correlations between RFI and MilkE, MY, MBW, and BW (Table 4) were especially present in US, albeit SE were still large. When estimated more precisely, these estimated genetic correlations should be taken into account when breeding objectives are defined, rather than assuming that RFI is independent of the underlying traits such as milk production and BW (Kennedy et al., 1993; Veerkamp et al., 1995).

\section{Predicting Feed-Intake-Related Traits from Conformation Traits}

DMI and RFI. The genetic correlations between DMI and ST, CW, and BD were moderate to high (0.33,

Table 8. Heritabilities and genetic correlations for production and conformation traits within and between the Netherlands (NL) and the United States (US; from Interbull, Holstein USA, and CRV)

\begin{tabular}{lccc}
\hline & \multicolumn{1}{c}{$\begin{array}{c}\text { US h } \\
\end{array}$} \\
Trait & $\begin{array}{c}\text { NL h } \\
(\text { CRV } 2014)\end{array}$ & $\begin{array}{c}\text { (Interbull, 2014; } \\
\text { Holstein Association } \\
\text { USA, 2014) }\end{array}$ & $\begin{array}{c}\text { NL-US genetic } \\
\text { correlations } \\
\text { (Interbull, 2014) }\end{array}$ \\
\hline Milk & 0.49 & 0.30 & 0.91 \\
Fat & 0.52 & 0.30 & 0.89 \\
Protein & 0.41 & 0.30 & 0.86 \\
Stature & 0.52 & 0.42 & 0.93 \\
Chest width & 0.24 & 0.31 & 0.82 \\
Body depth & 0.31 & 0.37 & 0.89 \\
Angularity & 0.11 & 0.29 & 0.69 \\
Rump angle & 0.34 & 0.33 & 0.96 \\
Rump width & 0.40 & 0.26 & 0.82 \\
BCS & 0.30 & 0.29 & 0.71 \\
\hline
\end{tabular}


0.45 , and 0.26 in NL, respectively, and $0.57,0.61$, and 0.49 in US). The largest estimated genetic correlation was between DMI and CW in both countries. The correlations were larger than the correlations estimated by Veerkamp and Brotherstone (1997) in the UK-Langhill population for heifers and cows separately (i.e., 0.18, 0.25 , and 0.20 , respectively, for heifers, and $0.32,0.28$, and 0.34 for cows). Parke et al. (1999) reported negative genetic correlations between gross feed efficiency (FCM yield/total energy intake) and ST (-0.36) and RW ( -0.31$)$, but these correlations cannot directly be compared with the genetic correlations with RFI estimated in our study.

The RFI was also genetically negatively correlated with BCS $(-0.24)$ in NL. However, in US, the genetic correlation between RFI and BCS was positive (0.14) but not different from zero due to the large SE (0.17). Therefore, it is unclear across the 2 countries what the effect of selection for RFI is on BCS.

The accuracies obtained in the selection indices were relatively high for the prediction of DMI, up to 0.74 in NL and 0.95 in US when accurate breeding values for conformation and yield are combined. For RFI the accuracy in US was high, but low in NL. These high accuracies demonstrate the potential of using predictor traits to select the most efficient animals. However, the nature of the accuracy calculations is that they are probably overestimated, especially when SE of the estimated genetic parameters are large. Also, taking into account that the energy sinks explain about 62 and $67 \%$ (100\% minus $38 \%$ and $33 \%$, respectively) of the variation in DMI in NL and US, it is unlikely that type traits will predict RFI so accurate. A possible explanation for the overestimated prediction accuracy might be the high SE (0.12 to 0.19) of the genetic correlations between the trait in the breeding goal and the predictor traits. Sales and Hill (1976) and Hill and Thompson (1978) have previously demonstrated that accuracies tend to be overestimated when genetic correlations have large SE. Therefore, it is too early to conclude that DMI or RFI does not need to be recorded anymore, even though the predictors gave an accuracy of 0.97. An important remaining question is how much of the genetic variation in DMI can be explained by easy-to-measure predictor traits.

MY and MilkE. Low negative genetic correlations between MY and BCS have been previously estimated by several authors (Veerkamp and Brotherstone, 1997; Veerkamp et al., 2001; Kadarmideen and Wegmann, 2003; Bastin and Gengler, 2013), ranging from -0.12 to -0.38 . On the other hand, the genetic correlations of MilkE and MY with ANG in NL (0.33 and 0.44, respectively), and between MilkE and BD (0.45) and between
MY and ANG (0.48) in US were slightly higher than the ones reported by Zink et al. (2014; 0.19 between $\mathrm{MY}$ and $\mathrm{BD}$ and 0.32 between MY and ANG). The estimated correlations between MY and ANG in both countries should be interpreted carefully due to recent changes in the definition of ANG (CRV, 2014), and whether or not ANG is in fact the same trait in both countries.

$\boldsymbol{B} \boldsymbol{W}$. Body weight was highly genetically correlated with BCS in both countries (0.83 in NL and 0.85 in US). This correlation has been reported previously in the literature to range between 0.44 and 0.67 (Berry et al., 2003a; Muller et al., 2006; Vallimont et al., 2010). The correlations estimated in the current study were, therefore, higher than reported previously in the literature. Chest width was also highly positively correlated with BW. Finally, BW was negatively correlated with ANG; this was expected due to the estimated negative genetic correlation between ANG and BCS ranging between -0.38 to -0.65 (Bastin and Gengler, 2013; Battagin et al., 2013). Veerkamp and Brotherstone (1997) demonstrated how the correlations between conformation traits and BW changed depending on if BW was (genetically) adjusted to a common BCS or not. The correlation of BW with ANG and CW decreased considerably, and also the zero correlations between yield and BW became positive when BW was adjusted for BCS. Hence, this suggests that many components that contribute to variation in BW such as gut fill, body fat, bones, and muscle have differential nutritional requirements for maintenance. Therefore, linear conformation traits might be better as predictors of maintenance costs because they allow for the separation of different body components (i.e., a fat small cow versus a thin tall cow that have the same weight).

\section{Implications}

Given that the heritability is an important factor for the calculation of the size of the reference population for genomic prediction (Daetwyler et al., 2008, 2010), the results from this study can be used to decide on the size of the reference population for DMI for separate countries. Based on a country-specific heritability for DMI of 0.32 in NL and 0.29 in US, and assuming the proportion of independent chromosome segments to be 0.75 , and assuming 1,000 individuals in the effective size of the training population, the accuracy of genomic prediction of DMI would be 0.50 in NL and 0.48 in US, following Daetwyler et al. (2010). To reach an accuracy of 0.50 in US as well, we would need 1,104 animals with DMI recorded in the training set instead of 1,000 . This example shows the importance of accurate recording 
and of the heritability in the genome-wide evaluation approach for novel traits.

Furthermore, the importance of the results of this study is beyond the use of conformation traits as a predictor of feed-intake-related traits, but also to understand how those traits are genetically correlated with each other. Estimated genetic correlations between feed-intake-related traits and conformation traits can be used to estimate how the indirect selection would affect those traits (given that selection of one trait would affect all the traits correlated with it) and predict the correlated response. Also, the generated information can be used to be included in a multiple trait selection index fitting several traits simultaneously.

\section{CONCLUSIONS}

Estimated heritabilities for feed-intake-related traits and conformation traits were higher in NL than in US, and genetic correlations between feed-intake-related traits and conformation traits were higher in US than in NL. Despite these differences, the heritabilities and genetic correlations between feed-intake-related traits and conformation traits showed the same pattern in both countries. Dry matter intake can be predicted with accuracies up to 0.43 in NL and 0.64 in US by a combination of conformation traits (ST, CW, and BD), and up to 0.74 in NL and 0.95 in US when MilkE is added to the index. However, these accuracies should be taken with caution because they may be overestimated given the high SE of the estimated genetic correlations between the target and the predictor traits. Therefore, recording DMI recording continues to have a high priority.

\section{ACKNOWLEDGMENTS}

The data collection was financed by the Dutch Dairy Board (Zoetermeer, the Netherlands), the Dutch Product Board Animal Feed (Zoetermeer, the Netherlands), and CRV (Arnhem, the Netherlands). Funding for this project was also provided by Agriculture and Food Research Initiative Competitive Grant \#201168004-30340 from the USDA National Institute of Food and Agriculture. The first author thanks the National Council on Science and Technology of Mexico (CONACYT, Mexico) for its financial support for a $\mathrm{PhD}$ study at Wageningen University, and to the National Research Institute of Forestry, Agriculture and Livestock (INIFAP, Mexico) to promote the professional development of the researchers. Mario Calus (Wageningen UR Livestock Research, Wageningen, the Netherlands) and Jennie Pryce (Department of Economic Development,
Jobs, Transport \& Resources, Victoria, Australia) are kindly acknowledged for their helpful comments on this paper.

\section{REFERENCES}

Bastin, C., and N. Gengler. 2013. Genetics of body condition score as an indicator of dairy cattle fertility. A review. Biotechnol. Agron. Soc. 17:64-75.

Battagin, M., F. Forabosco, J. H. Jakobsen, M. Penasa, T. J. Lawlor, and M. Cassandro. 2012. International genetic evaluation of Holstein bulls for overall type traits and body condition score. J. Dairy Sci. 95:4721-4731.

Battagin, M., C. Sartori, S. Biffani, M. Penasa, and M. Cassandro. 2013. Genetic parameters for body condition score, locomotion, angularity, and production traits in Italian Holstein cattle. J. Dairy Sci. 96:5344-5351.

Beerda, B., W. Ouweltjes, L. B. J. Sebek, J. J. Windig, and R. F. Veerkamp. 2007. Effects of genotype by environment interactions on milk yield, energy balance, and protein balance. J. Dairy Sci. 90:219-228.

Berry, D. P., F. Buckley, P. Dillon, R. D. Evans, M. Rath, and R. F. Veerkamp. 2003a. Genetic parameters for body condition score, body weight, milk yield, and fertility estimated using random regression models. J. Dairy Sci. 86:3704-3717.

Berry, D. P., F. Buckley, P. Dillon, R. D. Evans, M. Rath, and R. F. Veerkamp. 2003b. Genetic relationships among body condition score, body weight, milk yield, and fertility in dairy cows. J. Dairy Sci. 86:2193-2204.

Berry, D. P., R. Buckley, P. Dillon, R. D. Evans, and R. R. Veerkamp. 2004. Genetic relationships among linear type traits, milk yield, body weight, fertility and somatic cell count in primiparous dairy cows. Ir. J. Agric. Food Res. 43:161-176.

Berry, D. P., M. P. Coffey, J. E. Pryce, Y. de Haas, P. Lovendahl, N. Krattenmacher, J. J. Crowley, Z. Wang, D. Spurlock, K. Weigel, K. Macdonald, and R. F. Veerkamp. 2014. International genetic evaluations for feed intake in dairy cattle through the collation of data from multiple sources. J. Dairy Sci. 97:3894-3905.

Berry, D. P., and J. J. Crowley. 2013. Cell Biology Symposium: Genetics of feed efficiency in dairy and beef cattle. J. Anim. Sci. 91:1594-1613.

Brotherstone, S. 1994. Genetic and phenotypic correlations between linear type traits and production traits in Holstein-Friesian dairy cattle. Anim. Prod. 59:183-187.

Brotherstone, S., M. P. Coffey, and G. Banos. 2007. Genetic parameters of growth in dairy cattle and associations between growth and health traits. J. Dairy Sci. 90:444-450.

CRV. 2014. E-08. Breeding value estimation for conformation traits. Accessed Apr. 15, 2015. https://global.crv4all. com/68143/67761/67689/e08conf.

Daetwyler, H. D., R. Pong-Wong, B. Villanueva, and J. A. Woolliams. 2010. The impact of genetic architecture on genome-wide evaluation methods. Genetics 185:1021-1031.

Daetwyler, H. D., B. Villanueva, and J. A. Woolliams. 2008. Accuracy of predicting the genetic risk of disease using a genome-wide approach. PLoS ONE 3:e3395.

de Haas, Y., M. P. L. Calus, R. F. Veerkamp, E. Wall, M. P. Coffey, H. D. Daetwyler, B. J. Hayes, and J. E. Pryce. 2012. Improved accuracy of genomic prediction for dry matter intake of dairy cattle from combined European and Australian data sets. J. Dairy Sci. 95:6103-6112.

de la Fuente, L. F., C. Gonzalo, J. P. Sanchez, R. Rodriguez, J. A. Carriedo, and F. San Primitivo. 2011. Genetic parameters of the linear body conformation traits and genetic correlations with udder traits, milk yield and composition, and somatic cell count in dairy ewes. Can. J. Anim. Sci. 91:585-591.

Dechow, C. D., J. Vallimont, M. D. Dekleva, J. M. Daubert, and J. W. Blum. 2010. Genetic correlations of gross feed efficiency with yield, 
body weight, body condition score, and energy balance in dairy cattle. J. Dairy Sci. 93(E-Suppl. 1):184. (Abstr.)

European Union. 2011. European Commission of Agricultural and Rural Development. Farm economics brief. no. 2. Production costs overview. Accessed Mar. 25, 2015. http://ec.europa.eu/ agriculture/rica/pdf/Brief201102.pdf.

Falconer, D. S., and T. F. C. Mackay. 1996. Introduction to Quantitative Genetics. 4th ed. Pearson Prentice Hall, Upper Saddle River, NJ.

Ferraretto, L. F., R. D. Shaver, and S. J. Bertics. 2012. Effect of dietary supplementation with live-cell yeast at two dosages on lactation performance, ruminal fermentation and total-tract nutrient digestibility in dairy cows. J. Dairy Sci. 95:4017-4028.

Ferraretto, L. F., R. D. Shaver, M. Espineira, H. Gencoglu, and S. J. Bertics. 2011. Influence of a reduced-starch diet with or without exogenous amylase on lactation performance by dairy cows. J. Dairy Sci. 94:1490-1499.

Gilmour, A. R., B. J. Gogel, B. R. Cullis, and R. Thompson. 2009 ASREML User Guide Release 3.0. VSN International Ltd., Hemel Hempstead, UK.

Harris, B. L., A. E. Freeman, and E. Metzger. 1992. Genetic and phenotypic parameters for type and production in Guernsey dairy cows. J. Dairy Sci. 75:1147-1153.

He, M., K. L. Perfield, H. B. Green, and L. E. Armentano. 2012. Effect of dietary fat blend enriched in oleic or linoleic acid and monensin supplementation on dairy cattle performance, milk fatty acid profiles, and milk fat depression. J. Dairy Sci. 95:1447-1461.

Hill, W. G., and R. Thompson. 1978. Probabilities of non-positive definite between-group or genetic covariance. Biometrics 34:429-439.

Holstein Association USA. 2014. Linear type evaluations. Accessed Apr. 15, 2015. http://www.holsteinusa.com/genetic_evaluations/ ss_linear.html.

Interbull. 2014. National genetic evaluation forms provided by countries. Accessed Apr. 15, 2015. http://www.interbull.org/ib/ geforms.

Kadarmideen, H. N., and S. Wegmann. 2003. Genetic parameters for body condition score and its relationship with type and production traits in Swiss Holsteins. J. Dairy Sci. 86:3685-3693.

Kennedy, B. W., J. H. J. Vanderwerf, and T. H. E. Meuwissen. 1993 Genetic and statistical properties of residual feed intake. J. Anim. Sci. 71:3239-3250.

Kleiber, M. 1932. Body size and metabolism. Hilgardia 6:315-353.

Koenen, E. P. C., and R. F. Veerkamp. 1998. Genetic covariance functions for live weight, condition score, and dry-matter intake measured at different lactation stages of Holstein Friesian heifers. Livest. Prod. Sci. 57:67-77.

Liinamo, A. E., P. Mantysaari, and E. A. Mantysaari. 2012. Short communication: Genetic parameters for feed intake, production, and extent of negative energy balance in Nordic Red dairy cattle. J. Dairy Sci. 95:6788-6794.

Manzanilla-Pech, C. I. V., R. F. Veerkamp, M. P. L. Calus, R. Zom, A. van Knegsel, J. E. Pryce, and Y. De Haas. 2014. Genetic parameters across lactation for feed intake, fat-and protein-corrected milk, and liveweight in first-parity Holstein cattle. J. Dairy Sci. 97:5851-5862.

Muller, C. J. C., S. W. P. Cloete, J. J. Olivier, J. A. Botha, and H de Waal. 2006. Heritability of live weight and condition score in a Holstein herd and correlations with milk traits-Preliminary estimates. S. Afr. J. Anim. Sci. 36:79-88.

National Research Dairy Council. 2001. Nutrient Requirements of Dairy Cattle. Natl. Acad. Press, Washington, DC.

Nixon, M., J. Bohmanova, J. Jamrozik, L. R. Schaeffer, K. Hand, and F. Miglior. 2009. Genetic parameters of milking frequency and milk production traits in Canadian Holsteins milked by an automated milking system. J. Dairy Sci. 92:3422-3430.

Parke, P., B. W. Kennedy, J. C. M. Dekkers, R. K. Moore, and L. Jairath. 1999. Genetic and phenotypic parameter estimates between production, feed intake, feed efficiency, body weight and linear type traits in first lactation Holsteins. Can. J. Anim. Sci. $79: 425-431$.
Potts, S. B., J. P. Boerman, A. L. Lock, M. S. Allen, and M. J. VandeHaar. 2015. Residual feed intake is repeatable for lactating Holstein dairy cows fed high and low starch diets. J. Dairy Sci. 98:4735-4747.

Sales, J., and W. G. Hill. 1976. Effect of sampling errors on the efficiency of selection indices. 2. Use of information on associated traits for improvement of a single important trait. Anim. Prod. 23:1-14.

Short, T. H., and T. J. Lawlor. 1992. Genetic parameters of conformation traits, milk-yield, and herd life in Holsteins. J. Dairy Sci. 75:1987-1998.

Spurlock, D. M., J. C. M. Dekkers, R. Fernando, D. A. Koltes, and A. Wolc. 2012. Genetic parameters for energy balance, feed efficiency, and related traits in Holstein cattle. J. Dairy Sci. 95:5393-5402.

Tempelman, R., D. Spurlock, M. P. Coffey, R. F. Veerkamp, L. Armentano, K. Weigel, Y. de Haas, C. Staples, E. E. Connor, Y. Lu, and M. VandeHaar. 2015. Heterogeneity in genetic and non-genetic variation and energy sink relationships for residual feed intake across research stations and countries. J. Dairy Sci. 98:2013-2026.

Tsuruta, S.. I. Misztal, and T. J. Lawlor. 2005. Changing definition of productive life in US Holsteins: Effect on genetic correlations. J. Dairy Sci. 88:1156-1165.

USDA. 2015. Agricultural productivity in the U.S. Accessed May 10, 2015. http://www.ers.usda.gov/data-products/agricultural-productivity-in-the-us.aspx\#28247.

Vallimont, J. E., C. D. Dechow, J. M. Daubert, M. W. Dekleva, J. W. Blum, C. M. Barlieb, W. Liu, G. A. Varga, A. J. Heinrichs, and C. R. Baumrucker. 2010. Genetic parameters of feed intake, production, body weight, body condition score, and selected type traits of Holstein cows in commercial tie-stall barns. J. Dairy Sci 93:4892-4901.

Van Dorp, T. E., J. C. M. Dekkers, S. W. Martin, and J. Noordhuizen. 1998. Genetic parameters of health disorders, and relationships with 305-day milk yield and conformation traits of registered Holstein cows. J. Dairy Sci. 81:2264-2270.

van Oers, K., and D. L. Sinn. 2011. From genes to Animal Behaviour: Social structures, personalities, communication by color. Page 171 in Toward a Basis for the Phenotypic Gambit: Advances in the Evolutionary Genetics of Animal Personality. M. Inoue-Murayama, S. Kawamura, and A. Weiss, ed. Springer, New York, NY.

Veerkamp, R. F. 1998. Selection for economic efficiency of dairy cattle using information on live weight and feed intake: A review. J. Dairy Sci. 81:1109-1119.

Veerkamp, R. F., and S. Brotherstone. 1997. Genetic correlations between linear type traits, food intake, live weight and condition score in Holstein Friesian dairy cattle. Anim. Sci. 64:385-392.

Veerkamp, R. F., M. P. Coffey, D. P. Berry, Y. de Haas, E. Strandberg, H. Bovenhuis, M. Calus, and E. Wall. 2012. Genome-wide associations for feed utilisation complex in primiparous Holstein-Friesian dairy cows from experimental research herds in four European countries. Animal 6:1738-1749.

Veerkamp, R. F., and G. C. Emmans. 1995. Sources of genetic variation in energetic efficiency of dairy cows. Livest. Prod. Sci. 44:8797.

Veerkamp, R. F., G. C. Emmans, A. R. Cromie, and G. Simm. 1995. Variance components for residual feed intake in dairy cows. Livest. Prod. Sci. 41:111-120.

Veerkamp, R. F., C. L. M. Gerritsen, E. P. C. Koenen, A. Hamoen, and G. De Jong. 2002. Evaluation of classifiers that score linear type traits and body condition score using common sires. J. Dairy Sci. 85:976-983.

Veerkamp, R. F., E. P. C. Koenen, and G. De Jong. 2001. Genetic correlations among body condition score, yield, and fertility in first-parity cows estimated by random regression models. J. Dairy Sci. 84:2327-2335.

Veerkamp, R. F., J. K. Oldenbroek, H. J. Van Der Gaast, and J. H. J. Van Der Werf. 2000. Genetic correlation between days until start of luteal activity and milk yield, energy balance, and live weights. J. Dairy Sci. 83:577-583. 
Veerkamp, R. F., G. Simm, and P. Persaud. 1994. Potential value of linear type traits for the prediction of intake, efficiency and economic margins in dairy cattle. Livest. Prod. Sci. 38:179-189.

Visscher, P. M., and M. E. Goddard. 1995. Genetic parameters for milk yield, survival, workability and type traits for Australian Dairy Cattle. J. Dairy Sci. 78:205-220.

Waltner, S. S., J. P. Mcnamara, and J. K. Hillers. 1993. Relationships of body condition score to production variables in high producing Holstein dairy cattle. J. Dairy Sci. 76:3410-3419.

WHFF. 2014. World Holstein Friesian Federation. Progress of type harmonisation. Accessed Mar. 18, 2015. http://www.whff.info/do cuments/2014TypeHarmonisationReportandRecommendations. pdf.

Yao, C., D. M. Spurlock, L. E. Armentano, C. D. Page Jr., M. J. VandeHaar, D. M. Bickhart, and K. A. Weigel. 2013. Random Forests approach for identifying additive and epistatic single nucleotide polymorphisms associated with residual feed intake in dairy cattle. J. Dairy Sci. 96:6716-6729.

Zink, V., M. Stipkova, and J. Lassen. 2011. Genetic parameters for female fertility, locomotion, body condition score, and linear type traits in Czech Holstein cattle. J. Dairy Sci. 94:5176-5182.

Zink, V., L. Zavadilova, J. Lassen, M. Stipkova, M. Vacek, and L. Stolc. 2014. Analyses of genetic relationships between linear type traits, fat-to-protein ratio, milk production traits, and somatic cell count in first-parity Czech Holstein cows. Czech J. Anim. Sci. 59:539-547.

Zom, R. L. G., G. Andre, and A. M. van Vuuren. 2012. Development of a model for the prediction of feed intake by dairy cows: 1 . Prediction of feed intake. Livest. Sci. 143:43-57. 